\title{
Fertilizer Nitrogen Uptake and Partitioning in Young and Mature Common Hackberry (Celtis occidentalis) Trees
}

\author{
L.P. Werner and L.G. Jull
}

\begin{abstract}
Twenty-one mature and thirty-six young common hackberry (Celtis occidentalis $\mathrm{L}$.) trees received a single application of ${ }^{15} \mathrm{~N}$ double isotope enriched ammonium-nitrate $\left(\mathrm{NH}_{4} \mathrm{NO}_{3}\right.$ ) fertilizer. Application rates were $0,0.49$, and $1.47 \mathrm{~kg} \mathrm{~N} 100 \mathrm{~m}^{-2}$ of canopy coverage, respectively. Foliage, current season stem wood, stem wood, root, and fruit tissues were analyzed for total concentration $[\mathrm{N}]$ and nitrogen derived from fertilizer (NDFF). Growth phase and application rate did not consistently affect total $\%[\mathrm{~N}]$, particularly the $\mathrm{N}$ demanding foliage. Growth phase and application rate significantly affected the percentage of NDFF. In every instance, NDFF was highest in the tissues of young trees and/or trees receiving the $1.47 \mathrm{~kg}$ $\mathrm{N} 100 \mathrm{~m}^{-2}$ application rate. Mature trees relied upon previously assimilated $\mathrm{N}$ to meet the annual demand for $\mathrm{N}$ to a greater extent than young trees.

Key Words. ANSI A-300; Celtis occidentalis; Fertilization; Hackberry; Nitrogen; Remobilization.
\end{abstract}

\begin{abstract}
Annual demands for nitrogen $(\mathrm{N})$ by woody perennial plants are met through a combination of soil $\mathrm{N}$ derived from the mineralization of organic residues, symbiotic relationships with bacteria capable of fixing atmospheric N, wet and dry atmospheric deposition, and the internal cycling of previously acquired $\mathrm{N}$ (Schneider et al. 1996; Cooke and Weih 2005; Millard et al. 2006). The relative contribution from each of these sources to meet the annual demand for $\mathrm{N}$ can vary within a growing season and over time (Weinbaum et al. 1987; Deng et al. 1989; Millard and Proe 1991; Weinbaum and Van Kessel 1998). Independent of location, trees display a logistic pattern of growth in which the annual rate of growth eventually slows over time (Weiner 2001). It is unclear if temporal shifts in the rate of growth are driven by reductions in the availability of essential mineral elements or a combination of genetic, environmental, and physical restrictions (Weiner 2001; Ryan et al. 2004; Johnson 2006; Ryan et al. 2006). Regardless of the causal agent(s), it is logical to assume there is a concomitant decline in the annual demand for resources (i.e., $\mathrm{N}$ ) necessary to support the growth and development of new tissues.

In urban landscapes, $\mathrm{N}$-based fertilizers are commonly used to supplement native sources of $\mathrm{N}$ to promote growth in landscape trees or to remediate identifiable $\mathrm{N}$ deficiencies [Smiley et al. 2002; American National Standards Institute (ANSI) 2011]. Currently, N application rates range from 0.25 to $1.96 \mathrm{~kg} \mathrm{~N} 100$ $\mathrm{m}^{-2}$ of canopy coverage, and should not exceed 1.96-2.94 kg N $100 \mathrm{~m}^{-2}$ annually (ANSI 2011). The proposed range in application rates is intended to provide latitude in annual application rates, so as to account for various management objectives (e.g., maintenance, growth promoting), the type of fertilizer applied (i.e., fast release versus slow release), soil type (e.g., coarse versus fine texture, low native fertility versus high native fertility), associated land management practices (i.e., turf grass fertilization), and the physiological state (i.e., health) of the tree being
\end{abstract}

treated. The basis for the range in application rates appears to be consistent with studies evaluating fertilizer-induced growth responses in young trees (Neely et al. 1970; Smith 1978; Neely 1980; van de Werken 1981; Struve 2002). The combination of demonstrated declines in tree growth rate and potential changes in the relative contributions from the various sources of $\mathrm{N}$ used to meet the annual demand suggest there is sufficient evidence to question the efficacy of extrapolating rates of fertilization derived from studies involving young trees onto mature trees.

The objectives of this study were to examine and compare patterns of fertilizer $\mathrm{N}$ uptake at rates consistent with the ANSI standards in young and mature common hackberry (Celtis occidentalis) trees growing in urban landscapes and to evaluate growth phase-related changes in the source(s) of $\mathrm{N}$ used to meet the current growing-season demand for $\mathrm{N}$.

\section{METHODS AND MATERIALS}

Common hackberry, a native tree to eastern and central United States and Canada, was used to evaluate fertilizer $\mathrm{N}$ uptake and partitioning at eight locations in Waukesha, Wisconsin, U.S. $\left(43^{\circ} \mathrm{N}\right.$ $\left.-88^{\circ} \mathrm{W}\right)$. Common hackberry is a riparian species capable of reaching heights of $15-21 \mathrm{~m}$ at maturity and is tolerant of air pollution, a wide range of soil types, $\mathrm{pH}$, and moisture regimes. As a result, it is used extensively as a street, park, and landscape tree (Dirr 1998).

Waukesha is located in southeastern Wisconsin. Mean growing season (May-September) temperatures range from $15.2^{\circ} \mathrm{C}$ to $23.2^{\circ} \mathrm{C}$, and the area averages $880 \mathrm{~mm}$ of rainfall annually (Wisconsin State Climatology Office 2002). Trees utilized in the study were growing in public terraces greater than $1.83 \mathrm{~m}$ wide in residential neighborhoods or in public parks.

A split-plot design was employed where eight homogeneous plots (four mature tree plots and four young tree plots), were 
established across the geographic extent of Waukesha. Trees were defined as mature if they were producing fruit and had been established in the landscape for at least twenty years. Young trees had an establishment period of less than five years, according to the City of Waukesha's forest inventory records, and were not bearing fruit. Three of the young tree plots were planted in 1998, with the remaining plot being planted in 1996. A distance of at least $15.3 \mathrm{~m}$ separated all trees within the plots. Fertilizer treatments were the sub-plot factor and consisted of three rates of $\mathrm{N}$ application, 0 [TRT 1, tap water, $<1 \mathrm{mg} \mathrm{L}^{-1} \mathrm{~N}(\mathrm{ppm})$ ], 0.49

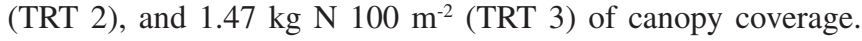
There were three trees per fertilizer treatment for the young tree plots and two trees per treatment in three of the four mature tree plots. The remaining mature tree plot had a single tree per treatment level because the canopies of the trees extended onto private property and limited access to the potential treatment area. A total of 57 trees were used in the study. All young trees were on a structural pruning cycle of 2,4 , and 6 years. All young tree locations were pruned during the same year (Liska, pers. comm.). Mature trees received a similar pruning cycle for the first 6 years following establishment and were then pruned on a 6-year cycle (Liska, pers. comm.). The City of Waukesha did not fertilize any of the study trees prior to the initiation of this work. All young trees received supplemental irrigation in periods of summer drought during the first two years of establishment.

Understory vegetation at all mature tree locations consisted of a mix of cool season turfgrasses. There was similar understory vegetation at two of the young tree plots, with vegetation at the remaining two plots consisting of annual and perennial herbaceous weeds. Soils at the plot locations were either silt loams, consisting of the Warsaw and Sawmill soil series, or a loam represented by the Hochheim soil series (USDA 1978). The Warsaw soil series (Typic Argiudoll) is a well-drained silt loam underlain by a calcareous sand and gravel outwash. The Sawmill soil series (Cumulic Haplaquoll) is a poorly-drained alluvial silt loam. Relative to the Warsaw soil series, the Sawmill series possessed a higher concentration of free carbonates. The Hochheim soil series (Typic Argiudoll) is a well-drained loam atop calcareous glacial till. A composite of four soil samples obtained from random locations within the area defined by the canopy drip line of each tree was analyzed at the University of Wisconsin-Madison Soil and Plant Analysis Laboratory (Verona, Wisconsin, U.S.) to determine soil $\mathrm{pH}$ (1:1 water), soil organic matter (SOM, \% loss on ignition), potassium $(\mathrm{K})$, and phosphorus ( $\mathrm{P}$, Bray $\mathrm{P} 1)$.

On June 12 and 13, 2001, $\mathrm{NH}_{4} \mathrm{NO}_{3}$ double enriched with ${ }^{15} \mathrm{~N}$ isotope (1.5 atom \% for both $\mathrm{NH}_{4}$ and $\mathrm{NO}_{3}$ ) was injected 15.2$25.4 \mathrm{~cm}$ below the soil surface at $1034 \mathrm{kPa}$ in a $0.6 \mathrm{~m} \times 0.6 \mathrm{~m}$ grid extending approximately $1.5 \mathrm{~m}$ beyond the canopy drip line. Component tissues from trees were sampled prior to treatment to establish baseline total $\mathrm{N}$ and ${ }^{15} \mathrm{~N}$ atom $\%$ values (Atkinson et al. 1987). Comparisons of fertilizer $N$ uptake and inferences surrounding rate of application and age class differences were determined based on changes in the concentration of ${ }^{15} \mathrm{~N}$ within plant tissues.

Tissue samples consisted of foliage, current season stem wood (new terminal stem tissue), older stem wood, fruit, and roots. Foliage samples were composed of developing and mature leaves obtained from branches receiving full sunlight located in the upper, mid, and lower portions of the crown. In young trees, current season stem wood samples consisted of a composite of terminal stem tissues from exterior branches, $15-25 \mathrm{~cm}$ in length, obtained from the upper, mid, and lower portions of the crown. Mature trees current season stem wood samples were obtained from exterior branches approximately $0.9 \mathrm{~m}$ in length that were in crown positions similar to those of young trees. Stem wood samples from young trees consisted of approximately 7-13 $\mathrm{cm}$ taken from the base of a limb $1.25 \mathrm{~cm}$ in diameter that was removed from the lower one-third of the crown. In mature trees, stem wood samples consisted of $15 \mathrm{~cm}$ (6 in) of limb wood obtained from lower branches approximately $7.6 \mathrm{~cm}$ in diameter. In young trees, approximately $25-50 \mathrm{~g}$ of woody and non-woody roots growing in the upper $25.4 \mathrm{~cm}$ of the soil profile were obtained equally from two samples beneath the crown. Approximately $150-250 \mathrm{~g}$ of woody and non-woody roots growing in the upper $25.4 \mathrm{~cm}$ of the soil profile were obtained equally from four locations under the crown of mature trees. In the field, soil was removed from root samples using two, five second rinses with deionized water. Fruit samples from mature trees were obtained during the acquisition of the foliar samples. Tissue samples were collected 14, 30, 60, 90, 120, and 150 days after fertilization and were dried at $60^{\circ} \mathrm{C}$ until processing in a Wiley mill (Thomas-Wiley Laboratory Mills, Philadelphia, Pennsylvania, U.S.) to pass a $1 \mathrm{~mm}$ sieve. One gram of the homogenized tissue was pulverized in a Crescent "Wig-L-Bug" Dental Amalgamator (Crescent Dental Manufacturing, Chicago, Illinois, U.S.) for 120 seconds using two, $5 \mathrm{~mm}$ stainless steel ball bearings at 5,000 rpm. Bark was included in the processing of current season stem wood and stem wood samples. Approximately $5 \mathrm{mg}$ of pulverized tissue were combusted at $1020^{\circ} \mathrm{C}$ in a Carlo-Erba Carbon : Nitrogen analyzer (Carlo Erba, Milan, Italy), interfaced with a Europa Scientific TracerMass mass spectrometer (Crew, Cheshire, United Kingdom). Analysis consisted of total N concentration $[\mathrm{N}]$ and percent ${ }^{15} \mathrm{~N}$ on a dry weight basis. Quality control was verified by duplicate analysis every 10-12 samples.

Comparisons of fertilizer accumulation in component tissues between mature and young trees were based on changes in the atom percent level of ${ }^{15} \mathrm{~N}$ relative to baseline (pre-fertilization) values and the level of isotopic enrichment in the fertilizer (NDFF $\%$ ) (Equation 1). Justification for using NDFF \% as a measure of fertilizer $\mathrm{N}$ recovery is supported by studies using destructive harvesting techniques (Kraimer et al. 2001). Specifically, fertilizer N recovery is the product of the level of ${ }^{15} \mathrm{~N}$ enrichment (NDFF \%) in component tissues and their respective biomasses. The percent nitrogen derived from fertilizer (NDFF) was calculated using a modified form of equations reported by Kraimer et al. (2001).

$$
\mathrm{NDFF}=\frac{(A-B)}{(C-D)}
$$

where $\mathrm{A}=\%{ }^{15} \mathrm{~N}$ in fertilized tissue sample, $\mathrm{B}=\%{ }^{15} \mathrm{~N}$ in tissues prior to fertilization, $\mathrm{C}=\%{ }^{15} \mathrm{~N}$ in fertilizer, and $\mathrm{D}=\%{ }^{15} \mathrm{~N}$ natural abundance $(0.366 \%$, IAEA 1983$)$.

The modification was necessitated by City of Waukesha imposed restrictions on the destructive harvesting of study trees. As a result, total tree biomass and component tissue (e.g. leaves, stem wood) biomass could not be determined.

Treatment and growth phase effects within a harvest period were determined using mixed model ANOVA procedures in SAS (Littell et al. 2004). Changes over time within the treatment structures of each growth phase were evaluated using repeated measures analysis. Treatment level and growth phase were fixed effects and location within a growth phase was a 
random effect in both analysis procedures. Scatter plots of residuals versus predicted values and the Kolmogorov-Smirnov test were used to test assumptions of normality. The log likelihood test was used to select the appropriate analysis model. Contrast statements were used to determine if responses in \% total $[\mathrm{N}]$ were linear or quadratic. Statistical analysis on the percentage of NDFF was performed on arcsin square root transformed data. Comparisons of treatment and growth phase effects were made using the Fisher's least significant difference test with $P \leq 0.05$.

\section{RESULTS}

\section{Soil Analysis}

Chemical characteristics, including soil $\mathrm{pH}, \mathrm{P}$ and $\mathrm{K}$ [mg $\left.\mathrm{L}^{-1}(\mathrm{ppm})\right]$, varied among the locations, however, all samples had similar lawn and garden interpretations of soil fertility as indicated by the University of WisconsinMadison Soil and Plant Analysis Lab (data not shown).

\section{Total $\mathbf{N}$}

The main effect of growth phase on total $\%[\mathrm{~N}]$ was significant in 11 of the $24(46 \%)$ sampling combinations (4 tissue types $\times$ 7 harvest periods, excluding tissue types or harvest periods that were not obtained) (Table 1). Differences between mature and young trees were most pronounced in the current season stem wood and stem wood and least evident in the foliage (Figure 1). Over time, the trend in total $\%[\mathrm{~N}]$ within a growth phase varied by stem tissue type. In the current season stem tissues of mature trees, total $\%[\mathrm{~N}]$ declined significantly between the pre-fertilization sampling period $(2.28 \%)$ and early dormancy at 150 days $(1.23 \%)$. In young trees, total \% [N] remained fairly constant throughout the study period, with no significant difference between pre-fertilization and dormancy values, $1.65 \%$ and $1.62 \%$, respectively. Total $\%[\mathrm{~N}]$ in the current season stem wood of mature trees was significantly higher than young trees through 60 days; however, continuing declines in total \% [N] through 150 days within the mature trees resulted in significantly higher total $\%[\mathrm{~N}]$ in young trees, $1.23 \%$ versus $1.62 \%$, respectively. Stem wood total $\%[\mathrm{~N}]$ tended to increase in both young and mature trees. At 150 days stem wood total \% [N] was 33\% and $35 \%$, higher than values observed prior to fertilization for young and mature trees, respectively. From 60 days through 150 days after fertilization, total $\%[\mathrm{~N}]$ in the stem wood of mature trees was significantly higher than values observed in young trees.

The main effect of application rate on total $\%[\mathrm{~N}]$ was significant in 3 of the $24(12.5 \%)$ sampling combinations (5 tissue types and 7 harvest periods, excluding tissue types or harvest periods that were not obtained) and was observed in the foliage, stem wood, and root tissues (Table 1). Responses to the rate of application were never evident for more than one harvest period per tissue type and each tissue type had a unique harvest period in which the rate of application was significant. Within the respective tissues and harvest periods, the response in total $\%[\mathrm{~N}]$ to an increasing rate of application was generally linear $(P<0.042$ for all analyses $)$. In those instances where significant differences were detected, total \% [N] in TRT 3 was $12 \%-20 \%$ higher than values observed in TRT 1 (Figure 2). During these harvest periods and within the tissue types, total \% [N] in TRT 2 did not differ from TRT 3.
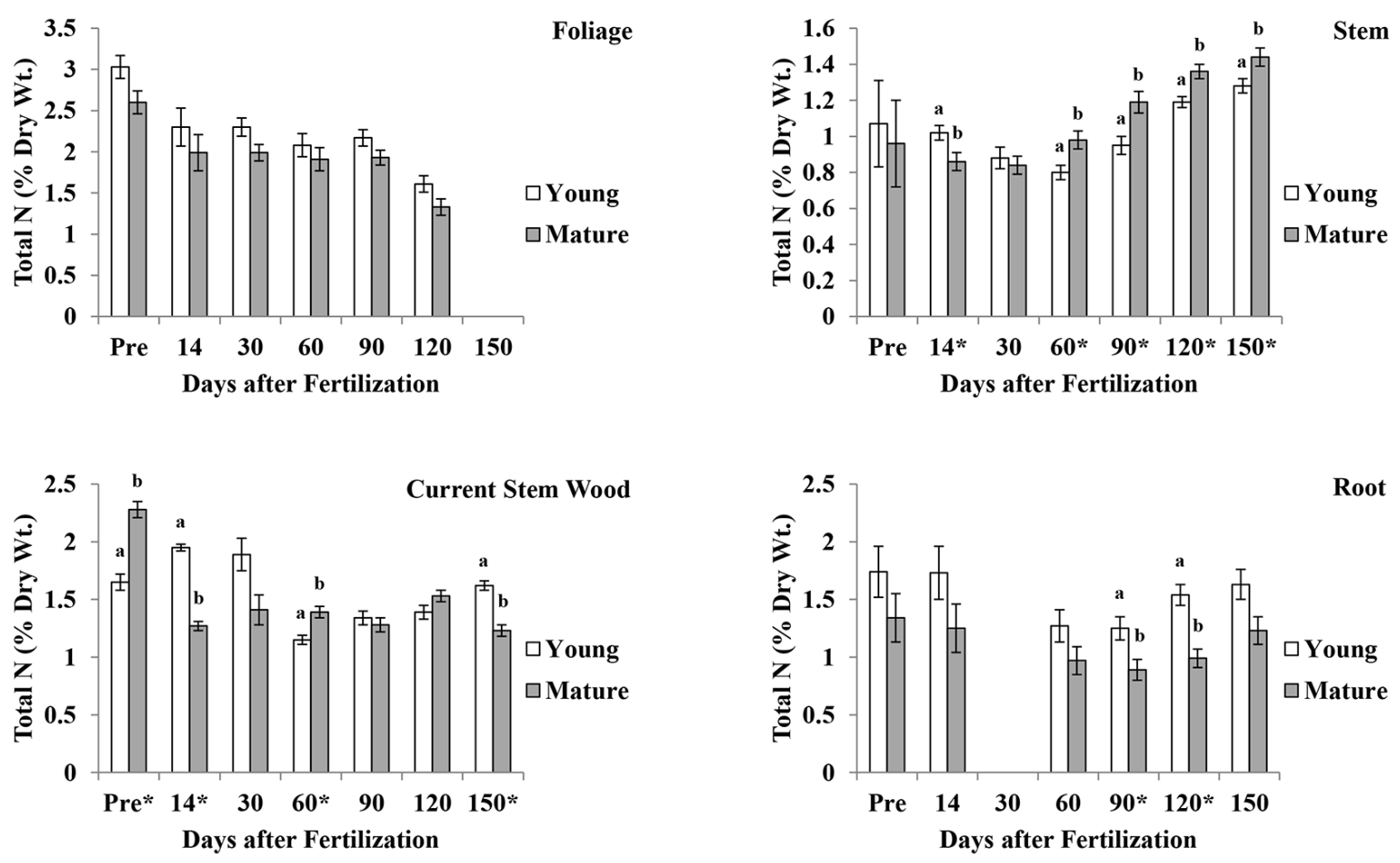

Figure 1. Effect of growth phase on total \% [N] in the tissues of common hackberry in 2001 in Waukesha. Bars represent the standard error of the mean. Asterisks (*) next to the harvest periods (days after fertilization) indicate significant differences between growth phases. Letters above bars that differ indicate significant treatment differences $(P<0.05)$ within a harvest period. 
Significant interactions between growth phase and the rate of application were observed in 3 of the $19(16 \%)$ potential sampling combinations (Table 1). Main effect interactions were observed in root tissues at 60 and 150 days after fertilization and at 14 days in the foliage. Within the root tissues, the rate of application affected total \% [N] in both growth phases; while growth phase differences were only observed within TRT 2 (data not shown). During both harvest periods, root total $\%[\mathrm{~N}]$ in mature trees receiving TRT 2 were $13 \%-33 \%$ and $17 \%-40 \%$ higher than values observed in TRT 1 and TRT 3, respectively. In young trees, TRT 3 produced root total \% [N] values that were 15\%-40\% higher than those observed in TRT 2 and TRT 1 . In the foliage, growth phase differences at 14 days were apparent in TRT $1(P=$ $0.011)$ and TRT $2(P=0.023)$, while the rate of application was significant only in the young growth phase $(P=0.026)$. In TRT 1 and TRT 2, foliar total \% [N] in mature trees was 37\%-69\% higher than corresponding values in young trees. Total \% $[\mathrm{N}]$ in the foliage of young trees receiving TRT 3 was $14 \%$ and $15 \%$ higher than values observed in TRT 1 and TRT 2, respectively.

Throughout the growing season and up to the initiation of leaf senescence ( 90 days), the ranking of $\%$ total $[\mathrm{N}]$ by tissue type was: foliage $\geq$ fruit $>$ current season stem wood $>$ roots $>$ stem wood. This trend occurred was observed in both growth phases and across all $\mathrm{N}$ levels.

\section{NDFF}

The main effect of growth phase on NDFF was significant in 13 of $19(68.4 \%)$ potential sampling combinations (6 harvest periods $\times$ 4 tissue types, excluding tissue types or harvest periods in which a sample was not obtained) (Table 2). Significant differences were observed in all tissues common to both growth phases. In every instance the percentage of NDFF was substantially greater in young trees, in some cases by as much as $300 \%$ (i.e., stem wood, Figure 3). NDFF tended to increase rapidly through 30 days in all tissues within a growth phase and then stabilized between 60 and 90 days after fertilization. For example, the percentage of NDFF in the foliage of both young and mature trees at the time of leaf senescence (120 or 150 days) was not significantly different than values observed at 30 days, $P<0.05$ in all instances.
The main effect of application rate was significant in 17 of 24 (70.8\%) potential sampling combinations ( 6 harvest periods $\times 5$ tissue types, excluding tissue types or harvest periods in which a sample was not obtained) and occurred in all tissue types (Table 2). In every harvest period, NDFF was substantially higher in the tissues of trees receiving TRT 3 (Figure 4). Generally, the magnitude of increase in the percentage of NDFF was not proportional to the threefold increase in the rate of application between TRT 2 and TRT 3 . In the foliage, current season stem wood, stem wood, and roots the percentage of back-transformed NDFF for trees receiving TRT 3 were 1.8, 1.6, 1.8, and 1.9 times higher, respectively, than same tissues in trees receiving TRT 2 . Within the fruit, the increase in NDFF associated with TRT 3 was 3.6 times higher than TRT 2 (data not shown).

Interactions between growth phase and the rate of application had significant effects on the percentage of NDFF in 6 of $19(31.6 \%)$ potential sampling combinations ( 6 harvest periods $\times$ 4 tissue types, excluding tissues or sampling dates that were not obtained) (Table 2). The interactions occurred only in the current season stem wood and stem wood. Within these harvest periods, the rate of application increased NDFF in the stem tissues within both; however, the magnitude of increase in response to the increasing $\mathrm{N}$ availability was greater in young trees. For example, NDFF in the current season stem wood increased, on average, by $130 \%$ and $250 \%$ in mature and young trees, respectively (data not shown).

In young trees, the percentage of NDFF by tissue type was foliage $>$ current season stem wood $>$ roots $>$ stem wood. In mature trees the percentage of NDFF by tissue type was fruit $\geq$ foliage $>$ current season stem wood $>$ root $>$ stem wood.

\section{DISCUSSION}

Nitrogen, regardless of its source, is preferentially allocated to actively growing and/or photosynthetic tissues (Neilsen et al. 1997; Weinbaum and Van Kessel 1998; Rose and Biernacka 1999; Mattos et al. 2003; Werner and Jull 2008). The higher concentrations of total $\%[\mathrm{~N}]$ in those tissues developed during the 2001 growing season in both growth phases and across all rates of application validate this fact. In deciduous trees, especially those displaying an indeterminate growth pattern, many of the high $\mathrm{N}$ tissues formed during the current growing season do not

Table 1. Analysis of Variance (ANOVA) of the effect of growth phase and application rate on percent \% total (N) in common hackberry tissues in 2001.

\begin{tabular}{|c|c|c|c|c|c|c|c|c|}
\hline \multirow[t]{2}{*}{ Tissue } & \multirow[t]{2}{*}{ Source } & \multicolumn{7}{|c|}{ Days after fertilization } \\
\hline & & Pre & 14 & 30 & 60 & 90 & 120 & 150 \\
\hline \multirow[t]{3}{*}{ Foliage } & Growth phase (GP) & 0.082 & 0.028 & 0.096 & 0.257 & 0.146 & 0.154 & $\mathrm{NA}^{\mathrm{z}}$ \\
\hline & Treatment (Trt) & & 0.277 & 0.073 & 0.046 & 0.052 & 0.363 & 0.869 \\
\hline & $\mathrm{GP} * \mathrm{Trt}$ & & 0.040 & 0.451 & 0.508 & 0.133 & 0.384 & NA \\
\hline \multirow[t]{3}{*}{ Current stem wood } & Growth phase (GP) & $<0.001$ & $<0.001$ & 0.061 & 0.008 & 0.223 & 0.372 & $<0.001$ \\
\hline & Treatment (Trt) & & 0.802 & 0.498 & 0.933 & 0.674 & 0.130 & 0.229 \\
\hline & $\mathrm{GP} * \mathrm{Trt}$ & & 0.597 & 0.229 & 0.086 & 0.053 & 0.803 & 0.756 \\
\hline \multirow[t]{3}{*}{ Stem wood } & Growth phase (GP) & 0.759 & 0.048 & 0.589 & 0.031 & 0.029 & $<0.001$ & 0.044 \\
\hline & Treatment (Trt) & & 0.690 & 0.041 & 0.245 & 0.647 & 0.066 & 0.823 \\
\hline & $\mathrm{GP} * \mathrm{Trt}$ & & 0.478 & 0.671 & 0.997 & 0.902 & 0.191 & 0.407 \\
\hline \multirow[t]{3}{*}{ Roots } & Growth phase (GP) & 0.587 & 0.253 & $\mathrm{NA}^{\mathrm{y}}$ & 0.143 & 0.037 & 0.039 & 0.068 \\
\hline & Treatment (Trt) & & 0.379 & NA & 0.019 & 0.370 & 0.003 & 0.022 \\
\hline & $\mathrm{GP} * \mathrm{Trt}$ & & 0.212 & NA & 0.002 & 0.054 & 0.416 & 0.026 \\
\hline
\end{tabular}

${ }^{\mathrm{z}}$ Leaves of young trees and fruit of mature trees not present at 150 days.

${ }^{\mathrm{y}}$ Tissues not collected at 30 days because of stress to canopy development in young trees. 

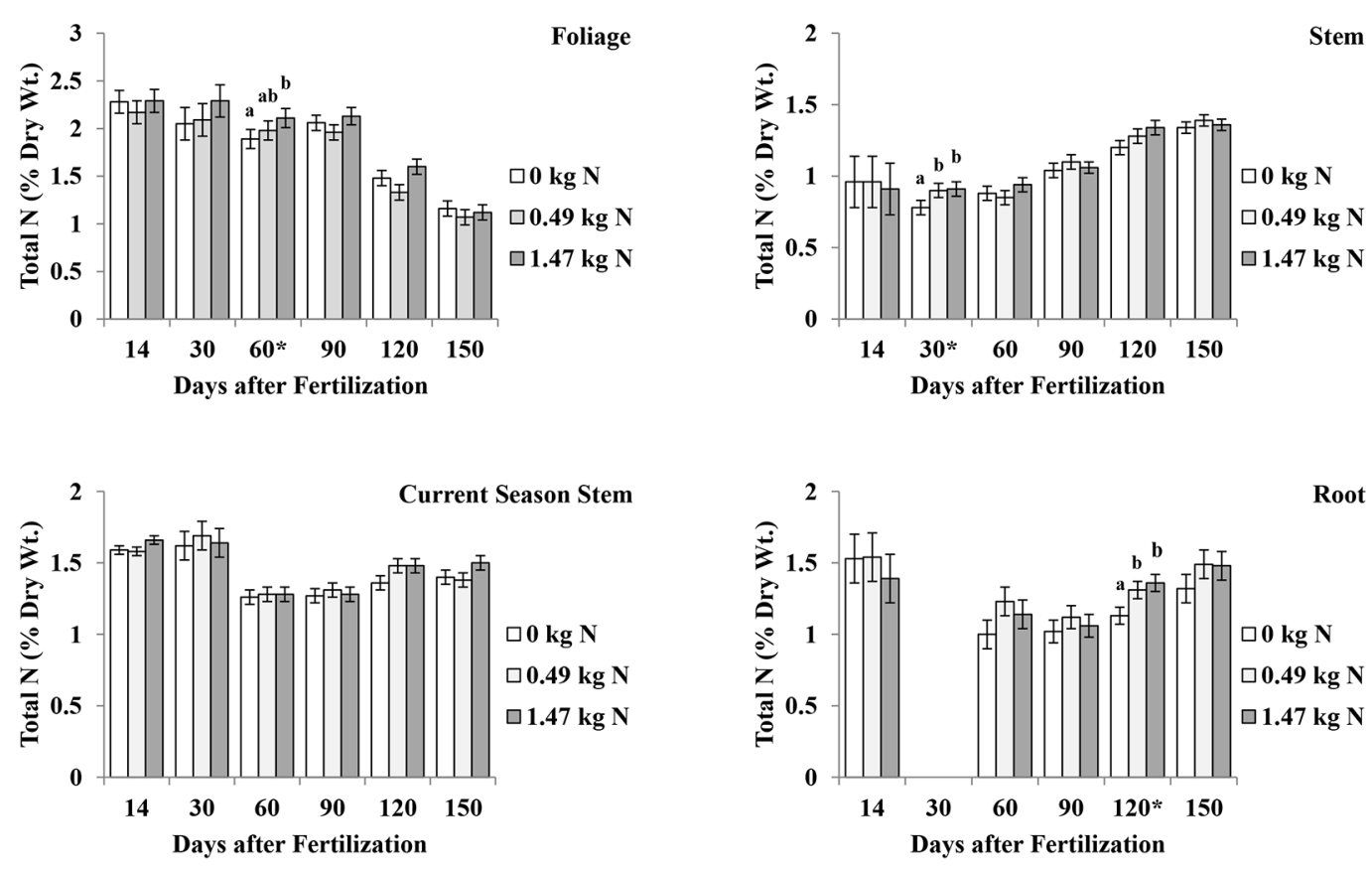

Figure 2. Effect of $\mathrm{N}$ application rate on total \% [N] in the tissues of common hackberry in 2001 in Waukesha. Bars represent the standard error of the mean. Asterisks $\left(^{*}\right)$ next to the harvest periods (days after fertilization) indicate significant differences between growth phases $(P \leq 0.05)$. Within a harvest period, columns with different letters are significantly different from one another $(P \leq 0.05)$.

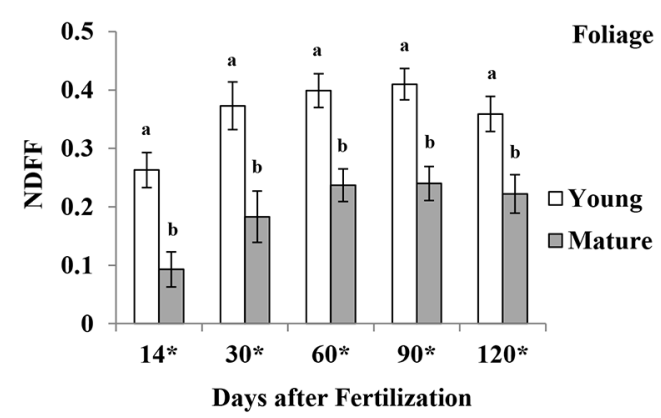

Current Season Stem

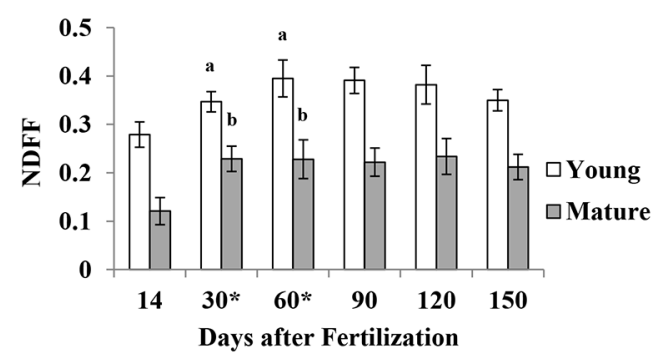

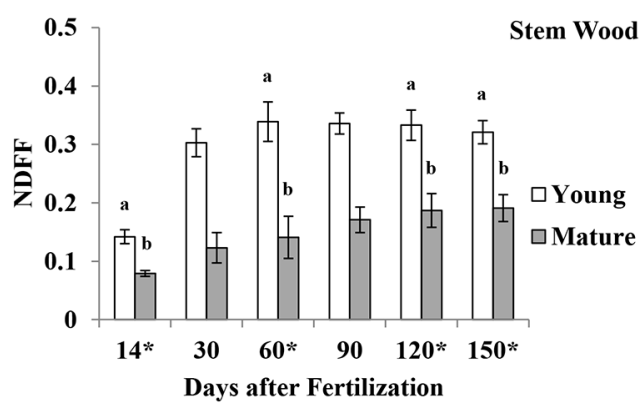

Root

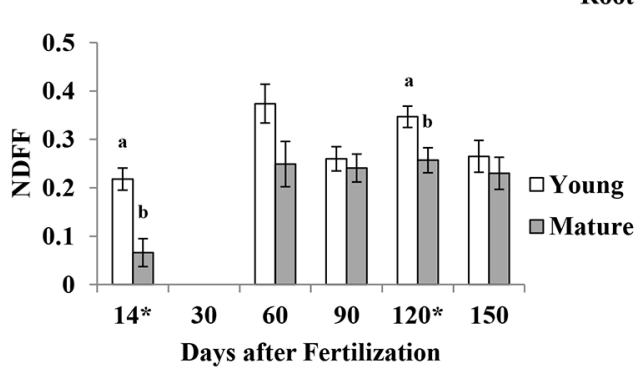

Figure 3. Effect of growth phase on the percentage of nitrogen derived from fertilization (NDFF) in the tissues of common hackberry in 2001 in Waukesha. Bars represent the standard error of the mean. Asterisks (*) next to the harvest periods (days after fertilization) indicate significant differences between growth phases $(P \leq 0.05)$ within a harvest period. 


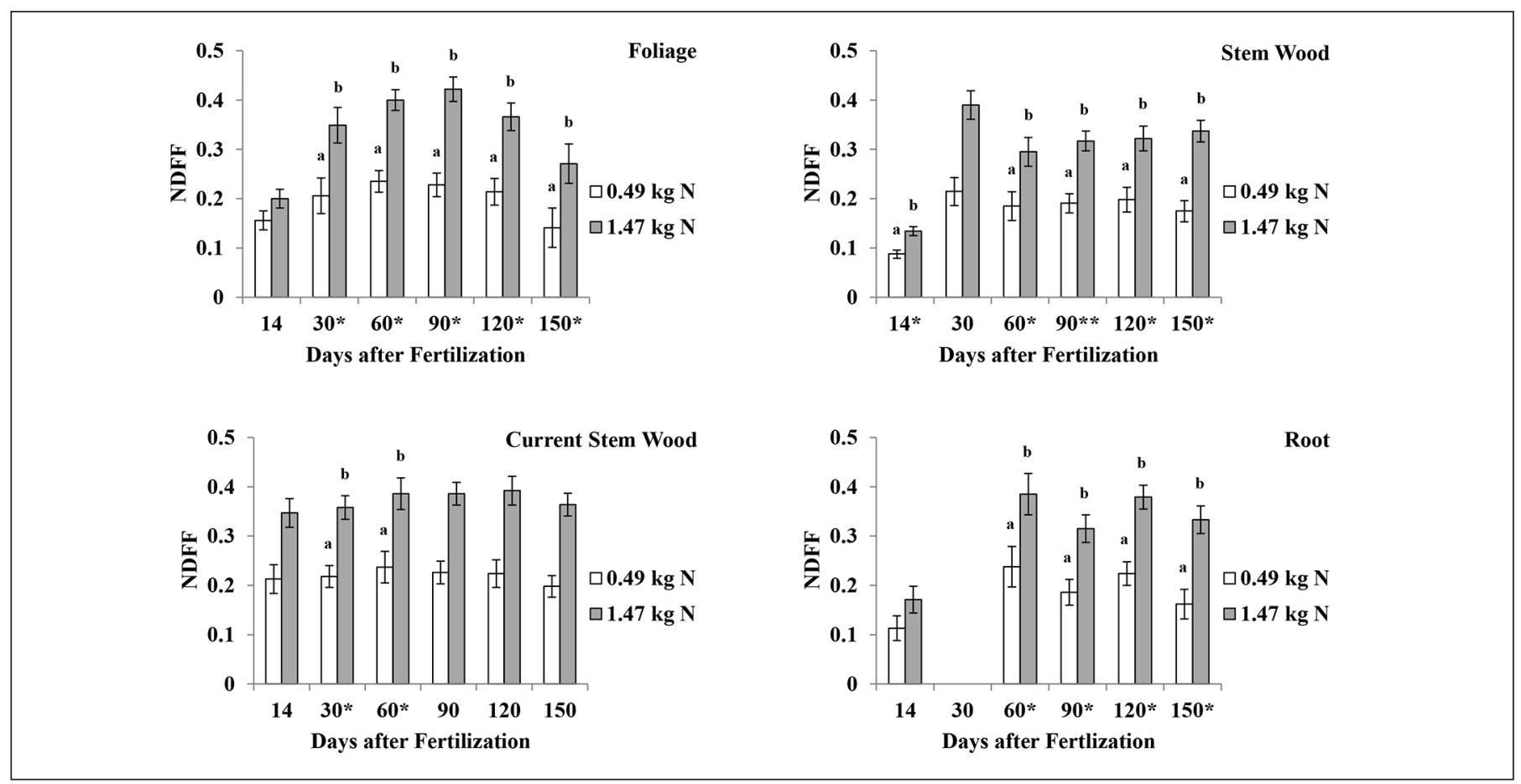

Figure 4. Effect of $\mathrm{N}$ application rate on the percentage of nitrogen derived from fertilization (NDFF) in the tissues of common hackberry in 2001 in Waukesha. Bars represent the standard error of the mean. Asterisks (*) next to the harvest periods (days after fertilization) indicate significant differences between rates of $\mathrm{N}$ application $(P \leq 0.05)$.

Table 2. Analysis of Variance (ANOVA) of the effect of growth phase and application rate on percent nitrogen derived from fertilizer (NDFF) in common hackberry tissues in 2001.

\begin{tabular}{|c|c|c|c|c|c|c|c|}
\hline \multirow[t]{2}{*}{ Tissue } & \multirow[t]{2}{*}{ Source } & \multicolumn{6}{|c|}{ Days after fertilization } \\
\hline & & 14 & 30 & 60 & 90 & 120 & 150 \\
\hline \multirow[t]{3}{*}{ Foliage } & Growth phase (GP) & 0.008 & 0.021 & $<0.001$ & 0.009 & 0.023 & $\mathrm{NA}^{\mathrm{z}}$ \\
\hline & Treatment (Trt) & 0.127 & 0.001 & $<0.001$ & $<0.001$ & $<0.001$ & 0.042 \\
\hline & GP $*$ Trt & 0.762 & 0.470 & 0.142 & 0.076 & 0.129 & NA \\
\hline \multirow[t]{3}{*}{ Current season stem wood } & Growth phase & 0.006 & 0.019 & 0.028 & 0.008 & 0.023 & 0.001 \\
\hline & Treatment & 0.007 & $<0.001$ & $<0.001$ & $<0.001$ & $<0.001$ & $<0.001$ \\
\hline & GP * Trt & 0.004 & 0.245 & 0.118 & 0.005 & 0.049 & 0.018 \\
\hline \multirow[t]{3}{*}{ Stem wood } & Growth phase & 0.001 & 0.003 & 0.004 & 0.008 & 0.010 & 0.008 \\
\hline & Treatment & 0.004 & $<0.001$ & $<0.001$ & $<0.001$ & $<0.001$ & $<0.001$ \\
\hline & GP $*$ Trt & 0.806 & 0.039 & 0.176 & 0.048 & 0.174 & 0.102 \\
\hline \multirow[t]{3}{*}{ Root } & Growth phase & $<0.001$ & $\mathrm{NA}^{\mathrm{y}}$ & 0.087 & 0.616 & 0.013 & 0.480 \\
\hline & Treatment & 0.121 & NA & 0.013 & 0.002 & $<0.001$ & $<0.001$ \\
\hline & $\mathrm{GP} * \mathrm{Trt}$ & 0.760 & NA & 0.480 & 0.761 & 0.351 & 0.081 \\
\hline
\end{tabular}

${ }^{\mathrm{z}}$ Leaves of young trees and fruit of mature trees not present at 150 days.

${ }^{y}$ Tissues not collected at 30 days because of stress to canopy development in young trees.

persist into the next growing season and are subsequently shed (e.g., leaves, fruit). Prior to shedding, a substantial amount of the $\mathrm{N}$ that had been preferentially partitioned to these tissues is removed and stored in perennial tissues (e.g., stems, roots) to meet future demands for N (Aerts 1996; Neilsen et al 1997; Cooke and Weih 2005; Millard et al. 2006). In this study, temporal declines in total $\%[\mathrm{~N}]$ within the strongest sinks for $\mathrm{N}$ during the growing season, chiefly the fruit and foliage, were accompanied by increases in total \% [N] within the stem tissues in both growth phases and at all rates of application. However, growth phase appeared to influence the pattern of remobilized $\mathrm{N}$ deposited within and among the various stem tissues. In young trees, the current season stem wood represented a stronger sink for remobilized N, while the stem wood represented a stronger sink in mature trees. The magnitude, and to a certain extent the efficiency of internal $\mathrm{N}$ cycling, appears to be a function of the size of the $\mathrm{N}$ pool within the senescing tissues relative to the capacity for storage within the perennial tissues (Diaz et al. 2008). In healthy trees, both 
the size of the $\mathrm{N}$ pool and the capacity to store $\mathrm{N}$ removed from senescing tissues increases as tree biomass accumulates with time/age (Nielsen et al. 1997). Therefore, the study authors suspect that observed increases in $\mathrm{N}$ accumulation within the current season stem wood of young hackberry trees, many of which die during the winter dormant season, diminishes the overall capacity of young trees to store $\mathrm{N}$. The combination of this diminished $\mathrm{N}$ storage capacity and a comparatively fast rate of growth in young trees would, therefore, increase the demand for $\mathrm{N}$ from the soil and/or other external sources to meet future demands for $\mathrm{N}$. Conversely, the enhanced $\mathrm{N}$ storage capacity and comparatively slow rate of growth in mature trees would appear to decrease the demand for soil derived $\mathrm{N}$, with the resulting deficit being offset by increases in the use of previously assimilated, stored $\mathrm{N}$ to meet the annual demand for $\mathrm{N}$ within developing and/or photosynthetic tissues. The combination of total \% [N] and the percentages of NDFF within the transient and perennial tissues of young and mature trees support this conclusion. With one exception, total $\%[\mathrm{~N}]$ within the $\mathrm{N}$ demanding foliage of mature trees was not significantly different from values observed in young trees; yet, the percentage of NDFF in the foliage of young trees was almost $200 \%$ greater than that of mature trees. The preferential use of unlabeled, stored $\mathrm{N}$ over the isotopic enriched soil $\mathrm{N}$ in mature trees appears to account for much of the discrepancy in the percentage of NDFF within these tissues. These findings are consistent with other studies (Nielsen et al. 1997, Weinbaum and Van Kessel 1998) and would appear to indicate that as trees age the demand for external sources of $\mathrm{N}$, including fertilizer $\mathrm{N}$, diminishes.

Over the course of the 2001 study period, the rate of application did not exert strong influence over total \% [N]. In those instances where it was significant, it primarily occurred at the highest rate of application and generally within the tissues of young trees. Typically, the percentage of NDFF increased with an increasing rate of application in both growth phases. However, increases in the percentage of NDFF within the tissues of young trees had a tendency to be proportional to the increase in the rate of application and substantially lower in mature trees. These findings suggest that fertilizer $\mathrm{N}$ uptake relative to the rate of application was higher in young trees. The observation that total $\%[\mathrm{~N}]$ in the fruit was functionally equivalent to that of the foliage throughout much of the growing season indicates the fruit of mature trees is without doubt a substantial sink for $\mathrm{N}$; one that could potentially offset the reduction in the amount of fertilizer $\mathrm{N}$ allocated to other tissues and increase whole plant fertilizer $\mathrm{N}$ uptake. In this study, however, the amount of fertilizer $\mathrm{N}$ partitioned to the fruit of mature trees would have to be more than double what was allocated to the leaves to make up for the observed foliar differences in the percentage of NDFF between young and mature tree. The data would seem to suggest that despite the additional sink represented by the fruit, the demand for external $\mathrm{N}$ in mature hackberry trees is less than that of young hackberry trees, with observed differences being offset through the internal cycling of previously acquired N. These findings and conclusions are consistent with Sanchez et al. (1992) who observed similar declines in the use of fertilizer $\mathrm{N}$ in mature 'Comice' pears (Pyrus communis) trees and linked the reductions to the preferential use of previously acquired/stored $\mathrm{N}$ to meet new foliar needs and/or the competition for newly acquired $\mathrm{N}$ by fruit tissues.

\section{CONCLUSION}

The combination of total $\%[\mathrm{~N}]$ and the percentage of NDFF in the aboveground tissues of mature hackberry trees, suggests an age-related change in the extent to which these trees acquire, utilize, and partition N. Mature trees utilized internal stores of previously assimilated $\mathrm{N}$ to a greater extent than young trees to meet the needs of $\mathrm{N}$ demanding tissues. Furthermore, the evidence for the preferential use of stored $\mathrm{N}$ in mature trees appears to be independent of the $\mathrm{N}$ application rate. In other words, adding more fertilizer $\mathrm{N}$ did not override the tendency for the preferential use of previously assimilated $\mathrm{N}$. Thus, the dependence upon soil-derived sources of $\mathrm{N}$ does not appear to grow exponentially with increasing canopy spread associated with age/size. The chronic fertilization of mature trees that produce low or infrequent fruit mass, particularly at the high end of the ANSI A-300 rates, could result in substantial amounts of fertilizer $\mathrm{N}$ moving into un-targeted sinks (e.g., ground water, atmosphere). It would appear from this data that nutrient management regimes extrapolated from recommendations developed for young trees may not be entirely appropriate for trees of all ages. Continued research is needed, for it is unclear if mature trees will increase uptake at lower rates of application or under multiple application scenarios. Additionally, there is a need for research that incorporates destructive harvesting, a wider range of fertilizer formulations, tree species, and landscape conditions.

Acknowledgments. This research was funded by the International Society of Arboriculture's TREE Fund, the Wisconsin Arborist Association, and a University of Wisconsin System Consortium grant. Use of trade names in this publication does not imply endorsement by the University of WisconsinMadison of products named, nor criticism of

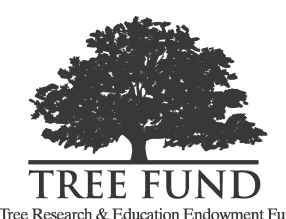
similar ones not mentioned. Technical assistance of Drs. Brian Yandell and Jun Zhu, Mr.'s. William Schmitt, Armand Krueger, and Peter Crump are gratefully acknowledged. Special consideration is given to the City of Waukesha, Wisconsin, and Mr. David Liska, City Forester, for providing research locations, equipment, and support personnel necessary to complete this study. From a dissertation submitted by L.P. Werner in partial fulfillment of the requirements for the Ph.D. degree.

\section{LITERATURE CITED}

Aerts, R. 1996. Nutrient resorption from senescing leaves of perennials: Are there general patterns? Ecology 84:597-608.

American National Standards Institute (ANSI). 2011. A300 (Part 2) Soil Management a. Modification, b. Fertilization, and c. Drainage. Tree Care Industry Association, Inc., Manchester, New Hampshire, U.S.

Atkinson, D., M.G. Johnson, C.M. Crisp, G. Maude, and E.R. Mercer. 1987. Variation in the natural enrichment of ${ }^{15} \mathrm{~N}$ in apple trees and soils. Journal of the Science of Food and Agriculture 38:19-22.

Cooke, J.E.K., and M. Weih. 2005. Nitrogen storage and seasonal nitrogen cycling in Populus: Bridging molecular physiology and ecophysiology. New Phytologist 167:19-30.

Deng, X., S.A. Weinbaum, and T.M. DeJong. 1989. Use of labeled nitrogen to monitor transition in nitrogen dependence from storage to current-year uptake in mature walnut trees. Trees Structure \& Function 3:11-16.

Diaz, C., T. Lemaître, A. Christ, M. Azzopardi, Y. Kato, F. Sato, J.F. Morot-Gaudry, F. Le Dily, and C. Masclaux-Dabresse. 2008. Nitrogen recycling and remobilization are differentially controlled by leaf 
senescence and development stage in Arabidopsis under low nitrogen nutrition. Plant Physiology 147:1437-1449.

Dirr, M.A. 1998. Manual of Woody Landscape Plants: Their Identification, Ornamental Characteristics, Culture, Propagation, and Uses. 5th edition. Stipes Publishing Co., Champaign, Illinois, U.S.

International Atomic Energy Agency (IAEA). 1983. A Guide to the Use of Nitrogen-15 and Radioisotopes in Studies of Plant Nutrition: Calculations and Interpretations of Data. IAEA, Vienna, Austria.

Johnson, D.W. 2006. Progressive N limitation in forests: Review and implications for long-term responses to elevated $\mathrm{CO}_{2}$. Ecology 87:64-75.

Kraimer, R.A., W.C. Lindemann, E.A. Herrera, and B. McCaslin. 2001. Fate of ${ }^{15} \mathrm{~N}$-labeled fertilizer applied to pecan. Proceedings of Western Nutrition Management Conference 4:237-246.

Liska, D.P. 2012. City Forester, Retired - Waukesha, WI. Personal Communication.

Littell, R.C., G.A. Milliken, W.W. Stroup, and R.D. Wolfinger. 2004. SAS System For Mixed Models. 6th ed. SAS Institute, Cary, North Carolina, U.S

Mattos, Jr., D., D.A. Graetz, and A.K. Alva. 2003. Biomass distribution and nitrogen-15 partitioning in citrus trees on a sandy entisol. Soil Science Society of America Journal 67:555-563.

Millard, P., and M.F. Proe. 1991. Leaf demography and the seasonal internal cycling of nitrogen in sycamore (Acer pseudoplatanus L.) seedlings in relation to nitrogen supply. New Phytologist 117:587-596.

Millard, P., R. Wendler, G. Grassi, G. Grelet, and M. Tagliavini. 2006. Translocation of nitrogen in the xylem of field-grown cherry and poplar trees during remobilization. Tree Physiology 26:527-536.

Neely, D. 1980. Tree fertilization trials in Illinois. Journal of Arboriculture 6:271-273.

Neely, D., E.B. Himelick, and W.R. Crowley, Jr. 1970. Fertilization of established trees: A report of field studies. Illinois Natural History Survey Bulletin 53(4).

Neilsen, D., P. Millard, G.H. Neilsen, and E.J. Hogue. 1997. Sources of $\mathrm{N}$ for leaf growth in a high-density apple (Malus domestica) orchard irrigated with ammonium nitrate solution. Tree Physiology 17:733-739.

Rose, M.A., and B. Biernacka. 1999. Seasonal patterns of nutrient and dry weight accumulation in Freeman maple. HortScience 34:91-95.

Ryan, M.G., D. Binkley, J.H. Fownes, C.P. Giardina, and R.S. Senock. 2004. An experimental test of the causes of forest growth decline with stand age. Ecological Monographs 74:393-414.

Ryan, M.G., N. Phillips, and B.J. Bond. 2006. The hydraulic limitation hypothesis revisited. Plant, Cell Environment 29:367-381.

Sanchez, E.E., T.L. Righetti, D. Sugar, and P.D. Lombard. 1992. Effect of timing of nitrogen application on nitrogen partitioning between vegetative, reproductive and structural components of mature 'Comice' pears. HortScience 67:51-58.

Schneider S., A. Gebler, P. Wever, D. von Sengbusch, U. Hanemann, and H. Rennenberg. 1996. Soluble N compounds in trees exposed to high loads of N: A comparison of spruce (Picea abies) and beech (Fagus sylvatica) grown under field conditions. New Phytologist 134:103-114.

Smiley, E.T., S.J. Lilly, and P. Kelsey. 2002. Best Management Practices: Tree and Shrub Fertilization. International Society of Arboriculture, Champaign, Illinois, U.S.

Smith, E.M. 1978. Fertilizing trees and shrubs in the landscape. Journal of Arboriculture 4:157-161.

Struve, D.K. 2002. A review of shade tree nitrogen fertilization research in the United States. Journal of Arboriculture 28:252-263.
United States Department of Agriculture. USDA. 1978. Soil Survey of Waukesha County, Wisconsin. Dept. Agr. Soil Conserv. Serv., Washington, D.C., U.S.

van de Werken, H. 1981. Fertilization and other factors enhancing the growth rate of young shade trees. Journal of Arboriculture 7:33-37.

Weinbaum, S.A., I. Klein, and T.T. Muraoka. 1987. Use of nitrogen isotopes and a light-textured soil to assess annual contributions of nitrogen from soil and storage pools in mature almond trees. Journal of the American Society for Horticultural Science 112:526-529.

Weinbaum, S.A., and C. van Kessel. 1998. Quantitative estimates of uptake and internal cycling of ${ }^{15} \mathrm{~N}$-labeled fertilizer in mature walnut trees. Tree Physiology 18:795-801.

Weiner, J. 2001. The nature of tree growth and the "age-related decline in forest productivity." OIKOS 94:374-376.

Werner, L.P., and L.G. Jull. 2008. Fertilizer Uptake, Partitioning, and Recovery in Container-Grown Common Hackberry (Celtis occidentalis) Trees. Arboriculture \& Urban Forestry 35:252-262.

Wisconsin State Climatology Office. 2002. Waukesha Water Works (478937). Accessed 10/01/2006. <www.aos.wisc.edu/ sco/clm-history/ stations/470308>

L.P. Werner (corresponding author)

Associate Professor

College of Natural Resources - Forestry

1600 Franklin Street

University of Wisconsin-Stevens Point

Stevens Point, WI 54481. Corresponding Author

L.G. Jull

Associate Professor and Extension Specialist

Dept of Horticulture

1575 Linden Drive

University of Wisconsin-Madison, Madison

WI 53706-1590 
Zusammenfassung. 21 ausgewachsene und 36 junge Zürgelbäume (Celtis occidentalis L.) erhielten eine einmalige Applikation eines mit $15 \mathrm{~N}$ Doppel-Isotopen angereicherten Ammonium-Nitrat-Düngers (NH4NO3). Die Applikationsraten betrugen 0, 0.49 bzw. 1.47 kg N 100 m-2 der Kronenbedeckung. Blattmasse, der diesjährige Stammzuwachs, Stammholz, Wurzel und Fruchtgewebe wurden auf die totale Konzentration von N und auf den Stickstoff aus der Düngung (NDFF) hin analysiert. Die Wachstumsphase und Applikationsrate beeinflusste den totalen Stickstoffgehalt nicht maßgeblich, besonders das stickstoffzehrende Laub. Die Wachstumsphase und Applikationsrate beeinflusste aber signifikant den Stickstoffgehalt aus der Düngung (NDFF). In jeder Hinsicht war NDFF am höchsten in den Zellgeweben der jungen Bäume und/oder bei Bäumen mit der Applikationsrate von $1.47 \mathrm{~kg} \mathrm{~N} 100 \mathrm{~m}-2$. Ausgewachsene Bäume griffen zu einem größeren Ausmaß als junge Bäume auf das früher assimilierte $\mathrm{N}$ zu, um die jährlichen Anforderungen an Stickstoff zu bedienen.

Resumen. Veintiún árboles maduros y treinta y seis jóvenes de almez común (Celtis occidentalis L.) recibieron una sola aplicación de fertilizante isótopo doble de $15 \mathrm{~N}$ enriquecido de nitrato de amonio (NH4NO3). Las dosis de aplicación fueron 0.049 y $1,47 \mathrm{~kg}$ de N 100 $\mathrm{m}-2$ de la cobertura del dosel, respectivamente. Se analizaron tejidos del follaje, hojas, madera del tallo de la temporada actual, raíz y fruto para determinar la concentración total $[\mathrm{N}]$ y nitrógeno derivado del fertilizante (NDFF). La fase de crecimiento y la tasa de aplicación no afectan constantemente el \% total [N], en particular el follaje $\mathrm{N}$ exigente. La fase de crecimiento y la tasa de aplicación afectaron significativamente el porcentaje de NDFF. En todos los casos, NDFF fue más alta en los tejidos de los árboles jóvenes y/o árboles que recibieron dosis de aplicación de $1,47 \mathrm{~kg} \mathrm{~N} 100 \mathrm{~m}-2$. Los árboles maduros aprovechan en un grado mayor el $\mathrm{N}$ previamente asimilado para satisfacer la demanda anual del mismo que los árboles jóvenes. 